International Journal of Heritage, Tourism and Hospitality

journal homepage: https://ijhth.journals.ekb.eg

\title{
Metaphorical Use of Nature in Expressing Self-perfection from the Middle Kingdom till the Early of Ptolemaic Period
}

Mohammed Heragi ${ }^{a *}$, Mohamed Zien ${ }^{\mathrm{a}}$

${ }^{a}$ Faculty of Tourism and Hotels Luxor University, Egypt

ARTICLE INFO

Keywords:

Metaphors

Ancient Egyptian Literature

Self-perfection

Atoubiograghies

Instructions.

\begin{abstract}
Using metaphors of self-perfection and pride are considered clear and strong indication that the Egyptians gave care for their social image and the way it was presented for the readers of their literary texts. Therefore, they strived to present their self- perfection in an aesthetic and atypical way through a decorative and beautiful language. The study discusses representations of the self-perfection by the individuals in ancient Egyptian literature until the early Ptolemaic Period. The researcher argued that the ancient Egyptians were aware of how to draw pictures of their reality and characters in metaphorical way by using the most appropriate examples. For example, they used some natural elements like sun, moon, stars, flowers, plants, trees, flowing waters of the Nile and others because of their beautiful and beneficent nature. These metaphors express many moral aspects of ancient Egyptians' character such as greathearted, brave, trusted, sharp, lovable, and cool person.
\end{abstract}

C2020 Faculty of Tourism and Hotels, Fayoum University All rights reserved

\section{Introduction}

The ancient Egyptians experienced the land of Egypt with its sharp contrasts that exists between the valley with its flora and the deserts, with its relative drought and heat, which they inhabited in Predynastic Periods. They found what they wished for in that nature of the Nile Valley, which contains the water that they were always searching for and for which they abandoned the arid desert. They found the plants that they can eat, the flowers and trees that make them feel the beauty of nature and the shade that helps them to find refuge from the intense heat.
During the Old Kingdom, the ancient Egyptian literature provided a wealthy information describing the ancient Egyptians thoughts about the ideal morality of someone but without created imagery of this character, ${ }^{2}$ while the Middle Kingdom literature developed a new innovation by using pictorial expressions and metaphors, to express morals of the individual and their responsibility towards the society. ${ }^{3}$

The New Kingdom contexts continued in developing the Imageray expression of the selfperfection in a social way and in the religious sphere as well. These metaphors of perfection continued in late letrature with the Saite period renaissance. During the early Ptolimaic period,

* Corresponding author, email: mohammed_heragi@yahoo.com

2 Assmann, J. (2005), "axial "breakthroughs" in ancient Egypt " in Arnason, J.(ed), Axial Civilizations and World History, Leiden, p.140

3 Lichtheim, M. (1992), Maat in Egyptian autobiographies and related studies, OBO 120, Fribourg, 30. 
these expression of Self-perfection are clear in the language of the autobiographies of Petosiris tomb. ${ }^{4}$ In general, metaphor means: "a particular set of linguistic processes whereby aspects of one object are 'carried over' or transferred to another object, so that the second object is spoken of as if it were the first". 5

The standard theme of metaphoric use of selfperfection of the private people were centered around three majors:

A. Imitations of gods' aspects, as on stela (CG 20539) ${ }^{6}$ during Senosert I, his vizir Mentuhotep declared:

w3h-ib r sdm mdwt mity ntr $m$ wnwt.f

Attentive to hear a speech, alike to the god in his hour.

The expression " $w 3 h$-ib $r$ s $\underline{d}$ dm... mity ntr" a mtaphor connected with a clear listening that results in decisions, it is a virtue more insightful than being "calm" or "patient. ${ }^{7}$

B. Behaving like parents and kinship members towards the needy. A statue of the priest Hor, son of Iutjek (Cairo JE 37512) dates back to the $3^{\text {rd }}$ intermedaite period, ${ }^{8}$ Hor described himself in ametaphoric way:

it im(3) niwty sw mwt n $n g 3$ w

A father kind to the have-not, a mother to the needy. ${ }^{9}$

C. Immitation with elements of the beautiful nature to express the individual good nature, which will be itroduced througt this study.This paper aims at analizing the literary and rhetorical expressions using some elements of nature in a metaphorical way for expressing someone self-perfection. This will be achived through investigating and displaying examples from the autobiographies, religious texts and maxims that witnessed the influence of the elements of nature upon the ancient Egyptians' way of thinking and hence their way of expressing. When the ancient Egyptians

\footnotetext{
${ }^{4}$ Lefebvre G.(1924), Le tombeau de Petosiris, I, Cairo: IFAO, p.6; Menu B.(1994), "le Tombeau de Petosiris nouvel examen" BIFAO 94, 311-327.

${ }^{5}$ Hawkes T.(1972), Metaphor, London, p.1.

6 Lange, H.O. and H. Schäfer. (1908). Grab- und Denksteine des Mittleren Reiches im Museum von Kairo, II Berlin: Reichsdruckerei, 152.5-6.

${ }^{7}$ Lichtheim, M. (1997), Moral values in ancient Egypt, OBO 155, Fribourg, 79-80.
}

looked to night sky, they noticed the moon and the stars with their characteristics and hence they used them in their literature in their true meaning and sometimes in a metaphorical use. The same idea for other terms indicating nature such as the water, the Nile, the shade, the plants, the trees, the flowers, etc. These previous elements of nature will be displayed and discussed to show how did the ancient Egyptian used it in a metaphorical use for expressing someone's self-perfection in ancient Egypt.

\section{Discussion}

Universe. It can refer also to the Phenomena of the physical world, and to life in general as well. Within the various uses of the word today, "nature" often refers to geology and wildlife. The nature in its physical meaning contain many natural elements such as plants, water, rivers, stars, moon, sun, etc. ${ }^{10}$

The nature and the climate of Egypt has greatly influenced its civilisation. From earliest periods, the ancient Egyptian people's concepts, religious beliefs, art and literature were profoundly impacted by the natural elements and phenomena which either on the earth or on the sky. They were always aware of the surrounding environment and the influence of the natural forces upon their daily lives. Their meditation on the power of these natural forces lead them to regard some of them as a great creative forces. People worshipped the great natural forces either to acquire their benefits or to avoid their mischief. ${ }^{11}$

The ancient Egyptian literature language is a true mirror for the recognition of the ancient Egyptians to the surrounding natural elements.

\subsection{Metaphors of Water}

The life of ancient Egyptians was mainly centered on the Nile River and its water. This was reflected in their art, religion, writings, politics, and social life. The water of the Nile, together with canals, wells, and lakes were essential for daily life use,

\footnotetext{
${ }^{8}$ Kees, M. (1958). Der Vezir Hori, Sohn des Jutjek, ZÄS 83, 1958, 37.

${ }^{9}$ Lichtheim, Maat in Egyptian autobiographies, 87-88.

${ }^{10}$ Ducarme, F. \& Couvet, D. (2020). "What does 'nature' mean?", In: Palgrave Communications, Springer Nature, vol. 6.

11 Ions V. (1990), Egyptian Mythology, Peter Bedrick Books,.7.
} 
purification, and rituals. The River Nile was called in Egyptian Itrw- 3 . The ancient Egyptians worshiped several Gods and Goddesses associated with the Nile such as Hapi, Sobek and Khnum. The River Nile crosses an almost rainless desert from south to north carrying the waters of Lake Victoria more than 3,000 miles to the Mediterranean Sea. ${ }^{12}$ In the ancient times, it had at least 5 streams and more than 16 tributaries that ran into the sea. ${ }^{13}$

The Ancient Egyptians noticed the course of the River Nile flows smoothly. The tomb-stela of scribe and mayor of Nekheb and Innyt Paheri at ElKab of $18^{\text {th }}$ dynasty, reign of Thutmose I \& Queen Hatshepsut (fig.1), stand out as one of the most complete and inclusive of the New Kingdom. The text started with appeal of offering then an extensive vision of the afterlife and an extended moral self-presentation, He says: ${ }^{14}$

iw hsb.n.l $\underline{d} r w m$ šsw snb $m \check{s} s w n b n n s w t \underline{h t} n b t$

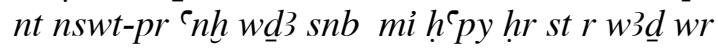
I counted the limits in the documents (papyrus rolls), the boundaries of all the king's concerns, all things that pertained to the palace (the king), like the Nile (Hapy) in its course to the sea.

The Egyptian phrase "mi hִpy hrr st $r w 3 \underline{d} w r$ " is corresponding to describe the visual image of smoothly flow of the Nile water to the Mediterranean Sea. As the Egyptians observed the Nile that was their main source for needed drinking water for living as well as annual flood which restored the life to the parched lands. ${ }^{15}$ In th Statue of Neshor, during the Pasmtik II, Saite Period:

Mw mš hrw ‘h了 3 ib hrw dmdyt shtp ibw wn knd nb hswthr ipt nbt

The water of the army in the day of fighting, the great of heart (on) the day of the gathering, the

12 Bruce, F. (2002), Gods of Ancient Egypt, Courier Corporation, 1.

13 Wendy, Ch. (2009), Empire of Ancient Egypt, Infobase Publishing, 9.

${ }^{14}$ Tylor, J. J, \& Griffith, F. LI. (1894), The Tomb of Paheri at El Kab, with Naville E., Ahnas el Medineh, $11^{\text {th }}$ memoir Egypt Exploration Fund, London, pp.2731; Urk IV, 111-123.

15 Rosalie, A. D. (1982), The Ancient Egyptians: Religious Beliefs and Practices, 74.

${ }^{16}$ Bassir, H. (2004), Image \& Voice in Saite Egypt, SelfPersentations of of Neshor Named Psamtikmenkhib and Paye-ftjau-emawy-neith, Wilkinson Egyptology Series, Volume 2, 48. one who satisfies the hearts of which were angry, possessor of favors in all accounts. ${ }^{16}$

The expression of "water of the army in the day of fighting" it is not one of actual military titles of Neshor as the provider of water for the army during battle. The expression here refers to Neshor as very brave and trusted and people depend on him like the importance of the water for soldiers in the day of battle. ${ }^{17}$

During the late period and early of Ptolemaic Period, at Tunal El-Gebel, Sishu father of Petosiris reported his piety and following the way of God "w3t ntr" imageray was used increasingly as a synonym for moral life (fig.2):

sšm.k ib.i $r$ šm hr $m w . k$

You guide my heart for walking at your water. ${ }^{18}$

The Metaphor of "šm hr $m w . k$ " to be on the way or water of the god is to be loyal to him and this is the way of life. Also, the primeval water was poured out for the deceased so as to rejuvenate him, to connect him with the gods, to cause him to ascend to the sky, and to create a space where he could return for his offerings. This water was the water of creation, which contained the cosmogonic impulses and energies. ${ }^{19}$

\subsection{Metaphors of Flowers and Trees for Beloved Person}

Egyptians used different plants and flower for mundane and otherworldly purpose for the living and the dead because of their beauty and their religious and magical symbolism. ${ }^{20}$ Therefore, presenting bouquets of flowers were common by the gods to the king, from the king to the gods, from the ruler to officials, by officials to a god or the king, or between private individuals. ${ }^{21}$

17 For water and food supplies for the army see; Spalinger, A. J. (2005), War in Ancient Egypt The New Kingdom, Oxford: Blackwell, 35-39, 46-52.

18 Taher, H. (2008), "Petosiris, the high priest of Hermopolis, his life and religious thoughts", unpublished Ph.D Dissertation, Minia university, p.188. 19 Assmann, J. (2011), Death and Salvation in Ancient Egypt, Cornell University Press, 363.

${ }^{20}$ Rosalie, Handbook to Life in Ancient Egypt, 362.

${ }^{21}$ Hartwig, M. (2004), Tomb Painting and Identity in Ancient Thebes, 1419-1372 BCE, Monumenta Aegyptiaca 10, 67; Examples in Dittmar, J. (1986), "Blumen und Blumensträusse als Opfergabe im Alten Ägypten", MÄS 43, 125 -132; Derchain Ch. (1953), La visite de vespasien au sérapéum d'Alexandrie. $C d E 28$, 261-279. 
During the Middle Kingdom, In Rediu-khnum's autobiography, Stela CG 20543, $11^{\text {th }}$ dynasty from Dendara (fig.3), he describes his professional skills and moral character: ${ }^{22}$

\section{ink wnnt sr 9 n ib.f hn bni $n$ mrwt}

I am truly an ofticial great of heart. a sweet lovable plant.

The Ramessid letter of Amenomope of $20^{\text {th }}$ dyaniasty, his friend described how Amenomope is a good noble as:

Noble of heart, goodly of qualities, adept in knowledge, beloved of all men, beautiful to him who beholds his charm, like a flower of the marshes in the heart of others (Mi iht hr ib $n$ $k y w y) .{ }^{23}$ Here the metaphor describes Amenomope as great-heart noble and among his people like " $a$ flower of the marshes in the heart of others". In the Book of Amenomope Instructions, chapter IV, there is a picture for the self-mastered person as the green tree with sweet fruits.

"The self-mastered person sets himself apart. He is like a tree grown in a meadow. It grows green, it doubles its harvest. It stands before its owner. Its fruit is sweet; its shade is pleasant. And it reaches its end among (other) trees." 24

In general, Egyptian imagery of human as flowers, plants and trees are very common because they saw the similarity as the plants and crops mature and die down, but they spring up again from the seed which has been put into the earth and has died. ${ }^{25}$ In the religious texts, Osiris, god of vegetation and the king of the underworld, for example symbolized this annual rebirth of the land and via his own resurrection was believed to be able to offer the eternal life to his worshippers. The nature and its elements affected the beliefs of the Egyptians who linked these natural phenomena with them in their existence and their hope for an eternal life. ${ }^{26}$

\subsection{Mataphors of Shade:}

${ }^{22}$ Lange-Schäfer, Grabsteine II, pp.165-166.

${ }^{23}$ Gardiner, Alan H. (1964), Egyptian Hieratic Texts, pp.6-7.

${ }^{24}$ Karenga, M. (2004), Maat the moral ideal in ancient Egypt, New York, 98-99.

${ }^{25}$ Zandee, J. (1960). Death as An Enemy. Leiden, p.1.

${ }^{26}$ Rosalie, The Ancient Egyptians, 74.

${ }^{27} \mathrm{~Wb} \mathrm{4,} \mathrm{432.1-5.}$

${ }^{28}$ See more about texts contain the delights of sycamore in Assmann, J. (2011), Death and Salvation
In ancient Egypt, the word the word $\breve{w}$ means protection or sunshade. ${ }^{27}$ Although the Egyptian soil was fertile, the country had a little number of indigenous plants; wildflowers are rare and native trees are few. The wild fig or sycamore is one of trees bearing dense foliage that grows in dry climate. There are some tomb paintings indicate that sitting in the shade of sycamore tree was considered as one of the delights of the life after death. ${ }^{28}$ Numberless inscriptions record the prayer that a man might sit in the shade of his sycamore and inhale the sweet cooling breeze of the north wind. In the autobiography of Harwa, the high steward of the divine wife of Amen, $25^{\text {th }}$ dynasty:

šwt $\underline{t} 3 . m-\ulcorner. f . h 3 r t$ nd

A shade for the child, A protector for the widow. ${ }^{29}$

Having the annual inundation of the Nile caused that the lands were under water for about four months in every year, other four months the lands of valley are green with growing crops and plants and the soil was bare during the rest four months of the year. Therefore, the natural shade caused by trees and plants was very little and does not remain for a long time. In addition to the rarity of the shade on the open areas, the weather of Egypt is sunny and hot especially to those who work on the hard labors in buildings and cultivating lands. For that reason, we think that the ancient Egyptians appreciated the existence of the shade. ${ }^{30}$

\subsection{Wishes of Being Like the Stars Metaphor}

The Ancient Egyptians were greatly interested in the night sky and in the stars. They were used to observe the bright stars for determining times and seasons of the year. They also used them in inscribing star-maps and tables in their coffins and tombs at least from the Middle Kingdom onward. It is known that different terms were used for expressing the word "star" such as $s w,{ }^{31}$

in Ancient Egypt, Cornell University Press, p. 216, 221, $231,452$.

${ }^{29}$ Gunn B. (1934), The Berlin statue of Harwa and some notes on other Harwa statues (with one plate), in: BIFAO 34, pp.135-142.

${ }^{30}$ The Gardeners' Chronicle: A Weekly Illustrated Journal of Horticulture and Allied Subjects, Volume 25, London, 1899, p. 461.

$31 \mathrm{~Wb} 4,57$. 
$s b 3,{ }^{32} s b 3 . t,{ }^{33} s h d,{ }^{34}$ gnh.t. ${ }^{35}$ For example, the word $s b A$ is written with the sign of a five pointed star $\checkmark$. The night sky was therefore referred to as kbh.w-sb3.w, ${ }^{36}$ often indicated "the starry firmament", but literally "the fresh water of the stars". ${ }^{37}$ In the Statue inscription (fig.4) of Fourth Prophet of Amen, Montemhet of $25^{\text {th }}$ dynasty, Nubian Period (Berlin 17271), after he counted his deeds and he made offering requests of being in the memory of the new generations:

w̧h.f rn.i mi sb3w nw pt smn.f hnty mi w` $m$ šmsw.f May he endure my name last like the stars of heaven, May my statue last like one of His followers. ${ }^{38}$

The expression w3h.f rn.i mi sb3w until the dead person wish of his life course through the name, which will guide the new generation similar to the stars. Some scholars as Faulkner ${ }^{39}$ suggested that the Pyramid Texts should be interpreted not only as funerary literature but also, more broadly, as religious literature. He supposed that they are part of the ancient Egyptian "star-religion" which describes the king's postmortem journey to the sky, and his transformation into a star, indicative of spiritualization. Many examples show the king becoming as a star such as "The King is a star" and "Pepi is a star that strews the sky" 40 and many other. Star-religion similar to the wide-spread sun cult, Re was one of the chief deities and the Egyptians noticed the continuous daily cycle of the sun and believed that it is an eternal course.

${ }^{32} \mathrm{~Wb} 4,82.7-83.4$.

${ }^{33} \mathrm{~Wb} 4,83.6$.

${ }^{34}$ This word was commonly used in its plural form sHd.w, 'stars'; Wb 4, 224.10-11; Van Der Molen, R., (2000), Hieroglyphic Dictionary of Egyptian Coffin

Texts. Leiden, p.527.

${ }^{35}$ Wb 5, 177.1-3; Wilson, Ptol. Lexikon, 1103.

${ }^{36} \mathrm{~Wb} 5,28.5$.

${ }^{37}$ Alford, A. F. (2004), The Midnight Sun: The Death and Rebirth of God in Ancient Egypt, p. 128.

${ }^{38}$ Lichtheim, M. (1980), Ancient Egyptian literature: A book of readings, Volume III: The Late Period,

Berkeley, Los Angeles, p.31.

${ }^{39}$ See more in Faulkner, R. O. (1966), "The King and the Star-Religion in the Pyramid Texts", JNES 25, pp.153-61.

${ }^{40}$ PT 570, § 1454a- 1455c.

${ }^{41}$ Rosalie, Handbook to Life in Ancient Egypt, p. 59.

${ }^{42} \mathrm{~Wb} 1,42.7-9$

${ }^{43}$ Ruiz A.(2001), The Spirit of Ancient Egypt, Algora Publishing, p. 271.
Therefore, they wanted to join the journey of this natural force; as they believed that the sunrise is equal to their birth, the course of the sun on the sky during the day is their lifetime and the sunset is their death. As they thought that the sun would ever die, the individual would ever die too because he or she is in the company of this huge natural force. ${ }^{41}$

\subsection{Wishes of Being Like the Moon Metaphor}

The ancient Egyptians considered the moon or $j^{c} h,{ }^{42}$ as one of the most important prominent celestial phenomena in the sky. They acknowledged its influence upon the Earth and upon their life and they linked it with their gods like Thoth and Khonsu.

From early periods, they observed the phases of the moon and after that, they counted and named the days of the lunar month as well. Therefore, the moon was the major regulator of the seasons for the Egyptians. ${ }^{43}$ It is from at least as early as the Old Kingdom that the Egyptians used three separate calendars; lunar, solar and civil. ${ }^{44}$

The lunar cycle with its different phases was believed to influence the daily life of the ancient Egyptians who dedicated stelae to it at Deir elMedina ${ }^{45}$ as well as forming personal names with the moon element. The Egyptians feared any interruption of the usual lunar cycle. A lunar eclipse was seen as a bad omen as it is mentioned in some Late Period texts which describe the sky swallowing the moon. ${ }^{46}$

44 The lunar calendar was one of the first invented calendars and it had twelve months and 354 days, this calendar was greatly followed and never abandoned throughout dynastic times. It determined most of the regional festivals for the temples and defined the periods of making offering at the tomb; see Spence, L. (2012), Ancient Egyptian Myths and Legends, Courier Corporation, pp.107\&176; Arnold, D. \& others (1997), Temples of Ancient Egypt, Cornell University Press, p.157.

${ }^{45}$ One of the stelae was dedicated by a woman called Inferti to the moon and the sun. She entreats the gods for to cure her from this ailment of blindness which she attributes to the malevolent words of some women. See the text in; Černý, J. (1958), Egyptian Stelae in Banks Collection, Oxford: Griffith Institute, no.6; Allen, J. P. (2005), The Art of Medicine in Ancient Egypt, Metropolitan Museum of Art, p. 22.

46 Austin, A. (2011), The Messianic Temple, Xulon Classic, p. 134. 
The moon was a symbol of rejuvenation due to its cycle. This can be understood from our metaphor of $4^{\text {th }}$ prophet Montemhet, Nubian dynasty (fig.4):

sh3 tw k3 im hwt-ntr.fr tr hrw whm rnpy mi ich May my ka be remembered in His temple night and day, May I renew my youth like the moon ${ }^{47}$.

The complete lunar cycle could be compared here to the life course of $4^{\text {th }}$ prophet Montemhet. ${ }^{48}$ It could also represent the old Montemhet who becomes once more, a youth.

\subsection{Absance of Other Elements of Nature Imagery:}

Through the previous metaphors, one can notice the absence of imitation of individuals by the birds, reptiles $^{49}$ and animals' aspects because of drawing a whole picture of individual's moral character.

In contrary, one can see the representations of the Kings and gods in animal images like lion, panther, fox or crocodile to express the kingship emotions and manners against the enemies. in Karnak Inscription of Merenptah, lines 15-16 expressing the Royal rage: ${ }^{50}$

ist h̆m.f $\underline{h}{ }^{\top} r w h r$.sn mi mủi

Now his majesty raged like a lion because of them. ${ }^{51}$

Thus, the animal imagery in the royal military texts is capable of showing extreme rage of the king and praised for his power and might in battle when dealing with foreign enemies and captives. ${ }^{52}$

\section{Conclusion}

The contexts of stelae, statues and the tombinscriptions from the Middle Kingdom till the early Ptolemaic Period that was used in this paper indicate the innovated feature of the ancient Egyptian elite literature in using the nature elements imagery in describing the perfect character.

${ }^{47}$ Lichtheim, Ancient Egyptian literature III, 31.

${ }^{48}$ Redford D. (2001), The Oxford encyclopedia of ancient Egypt, vol. 2, Oxford University Press, 481.

49 Through the transformation spells from the Old Kingdom Pyramids texts until the Graco-Roman Book of Transformations, one can observe the wishes of the deceased could assume non-human forms such as a falcon, goose, swallow, jackal, and scarab beetle, to give his ba the mobility through the power of transformation into these variety of birds, animals and other beings, thus the deceased can share in the livings community festivals see Smith M.(2009), Traversing Eternity Texts
These metaphorical expressions of nature elements convey the pride feeling of the indivduals towards the society as a direct result of their moral charcters which reflect an optimistic view towards their destiny. Their right doings during the course of their life assure their continuance between living communities like the stars and in the afterlife as well.

Metaphors of flowers, plants, trees, flowing waters were direct expressions for the self-perfection, while moon, stars metaphors were wishes of being remembered as perfect character, which indicate their care for their social image towards the readers of their texts in a rhetorical language.

In the other side, Egyptians' observation to identify certain elements of nature were clear as they neglected other elements like the birds, reptiles, and animal imagery for that kind literature about the moral personality.

\section{References}

Abo el Magd A. (2012). Animal imagery in expressing royal and divine rage. In proceedings of "Future Vision for development of Arabic tourism" 3rd international conference of Arabic Tourism, Association of Arab universities for tourism and hospitality, library of Alexandria, 1-12

Alford, A. F. (2004). The Midnight Sun: The Death and Rebirth of God in Ancient Egypt. Eridu Books.

Allen, J. P. (2005). The Art of Medicine in Ancient Egypt. Metropolitan Museum of Art.

Arnold, D. \& others (1997). Temples of Ancient Egypt. Cornell University Press.

Assmann, J. (2005) Axial "breakthroughs" in ancient Egypt. in Arnason, J. (ed), Axial Civilizations and World History, Leiden: Brill.

Assmann, J. (2011). Death and Salvation in Ancient Egypt. Cornell University Press.

Austin, A. (2011). The Messianic Temple. Xulon Classic.

Bassir, H. (2004). Image \& Voice in Saite Egypt, SelfPersentations of of Neshor Named

for the Afterlife from Ptolemaic and Roman Egypt, Oxford University Press, pp.610-666.

${ }^{50}$ Abo el Magd A. (2012), Animal imagery in expressing royal and divine rage in ancient Egyptian Texts, In proceedings of "Future Vision for development of Arabic tourism" $3^{\text {rd }}$ international conference of Arabic Tourism, Association of Arab universities for tourism and hospitality, library of Alexandria pp.1-12.

${ }^{51}$ KRI, IV, 4, 4; Manassa, C. (2003), The Great Karnak Inscription of Merneptah: Grand Strategy in the 13 ${ }^{\text {th }}$

Century B.C., pp. 27-28.

${ }^{52}$ Abo el magd, Animal imagery, p.10. 
Psamtikmenkhib and Paye-ftjau-emawy-neith. Wilkinson Egyptology Series: Vol.2.

Bruce F. (2002). Gods of Ancient Egypt. Courier Corporation.

Černý, J. (1958). Egyptian Stelae in Banks Collection, Oxford: Griffith Institute.

Cherpion N. \& Others (2007). Le tombeau de Petosiris a Touna el-Gebel releve photographique, Cairo: IFAO.

Derchain Ch. (1953). La visite de Vespasien au sérapéum d'Alexandrie. CdE 28, 261-279.

Dittmar, J. (1986). Blumen und Blumensträusse als Opfergabe im Alten Ägypten. MÄS 43, 125 132.

Ducarme, Frédéric \& Couvet, Denis (2020). What does 'nature' mean? In Palgrave Communications, Springer Nature, 6, 14 https://doi.org/10.1057/s41599-020-0390-y

Faulkner, R. O. (1966). The King and the Star-Religion in the Pyramid. JNES 25, 153-61.

Gardiner, Alan H. (1964), Egyptian Hieratic Texts, Hildesheim: Georg Olms Verlag.

Gunn B. (1934). The Berlin statue of Harwa and some notes on other Harwa statues (with one plate. BIFAO 34, 135-142.

Hartwig, M (2004). Tomb Painting and Identity in Ancient Thebes. 1419-1372 BCE. Monumenta Aegyptiaca 10, 1-26.

Hawkes T. (1972), Metaphor, London: Methuen and Co Ltd.

Ions V. (1990), Egyptian Mythology, Peter Bedrick Books.

Karenga, M. (2004), Maat the moral ideal in ancient Egypt, New York: Routledge.

Kees M. (1958). Der Vezir Hori, Sohn des Jutjek. ZÄS $83,129-138$.

Lange, H.O. and H. Schäfer. (1908). Grab- und Denksteine des Mittleren Reiches im Museum von Kairo, II Berlin: Reichsdruckerei.

Leclant J. (1961), "Montouemhat, quatrième prophète d'Amon", BDE 35, Cairo: IFAO.

Lefebvre G. (1924), Le tombeau de Petosiris, I, Cairo: IFAO.

Lichtheim, M. (1980), Ancient Egyptian literature: A book of readings, Volume III: The Late Period, Berkeley, Los Angeles: University of California Press.
Lichtheim, M. (1988). Ancient Egyptian Autobiographies Chiefly of the Middle Kingdom. Fribourg, Switzerland: Biblical Institute, University of Fribourg.

Lichtheim, M. (1992), Maat in Egyptian autobiographies and related studies. OBO120, Fribourg: Academic Press; Göttingen: Vandenhoeck \& Ruprecht.

Lichtheim, M. (1997), Moral values in ancient Egypt, OBO 155, Fribourg: Academic Press; Göttingen: Vandenhoeck \& Ruprecht.

Manassa, C. (2003), The Great Karnak Inscription of Merneptah: Grand Strategy in the 13th Century B.C., New Haven, Conn: Yale Egyptological Seminar.

Menu B. (1994). Le Tombeau de Petosiris nouvel examen. BIFAO 94, 311-327.

Redford D. (2001), The Oxford encyclopedia of ancient Egypt II, Oxford University Press.

Rosalie A. D. (1982). The Ancient Egyptians: Religious Beliefs and Practices, Routledge.

Rosalie A. D. (1999). Handbook to Life in Ancient Egypt, Oxford University Press.

Ruiz A. (2001). The Spirit of Ancient Egypt, Algora Publishing.

Smith M. (2009). Traversing Eternity Texts for the Afterlife from Ptolemaic and Roman Egypt, Oxford University Press.

Spalinger, A. J. (2005), War in Ancient Egypt The New Kingdom, Oxford: Blackwell.

Spence, L. (2012). Ancient Egyptian Myths and Legends, Courier Corporation.

Taher, H. (2008). Petosiris, the high priest of Hermopolis, his life and religious thoughts. unpublished Ph.D Dissertation, Minia university.

Tylor J. J, \& Griffith, F. LI. (1894). The Tomb of Paheri at El Kab, with Naville E., Ahnas el Medineh, $11^{\text {th }}$ memoir Egypt Exploration Fund, London:The Egypt Exploration Fund.

Van Der Molen, R. (2000). Hieroglyphic Dictionary of Egyptian Coffin Texts, Leiden: Brill.

Zandee, J. (1960), Death as An Enemy, Leiden: E.J. Brill. 


\section{Figures}

\section{Figure 1}

Tomb-Stela of the royal tutor Paheri,

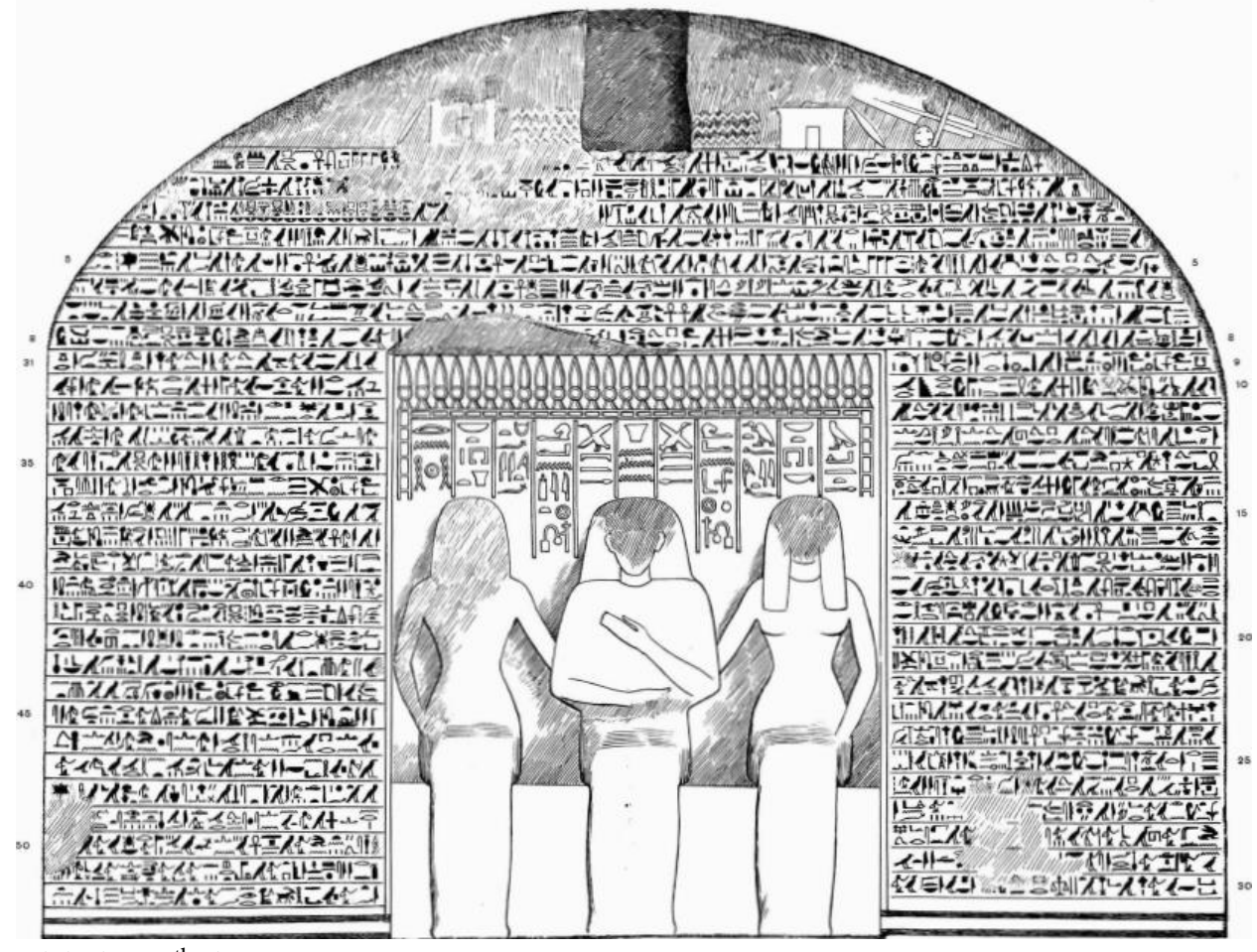

El-kab, $18^{\text {th }}$ dynastyTylor, The Tomb of Paheri at El Kab, pl. 9

Figure 2

Inscription of Sishu Father of Petosiris, Tuna El-Gebe

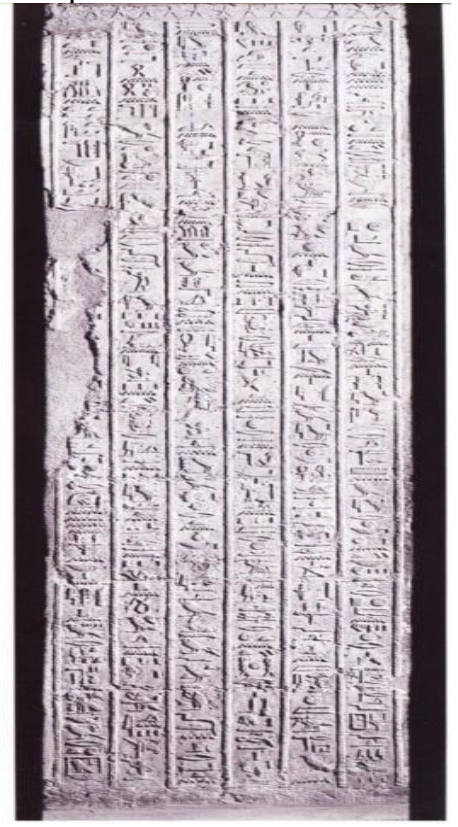

Cherpion N. \& Others (2007), Le tombeau de Petosiris a Touna el-Gebel releve photographique, IFAO, p.163
Figure 3

Stela of the Steward Rediu-Khnum of Dendara, Cairo CG 20543

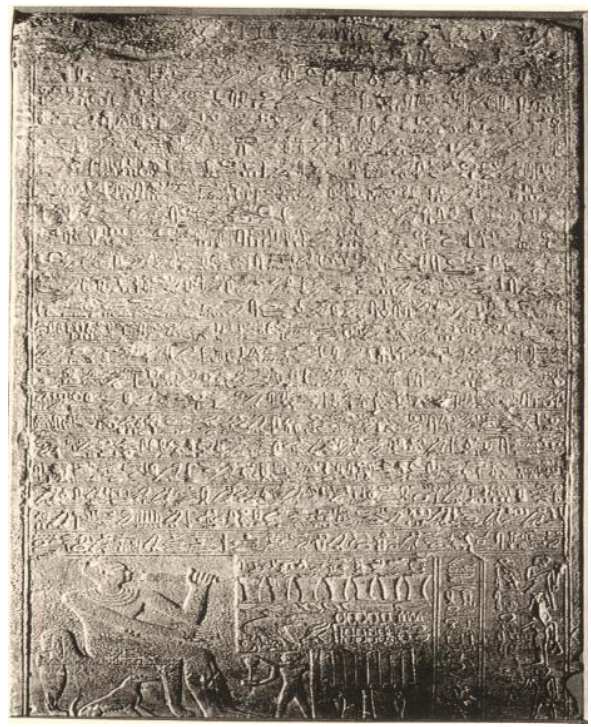

Lichtheim, M. (1988), Ancient Egyptian Autobiographies Chiefly of the Middle Kingdom. Fribourg, Switzerland: Biblical Institute, University of Fribourg, no.18, pl.1. 
Figure 4

Statue of Fourth Prophet of Amen, Montemhet of $25^{\text {th }}$ dynasty (Berlin 17271)
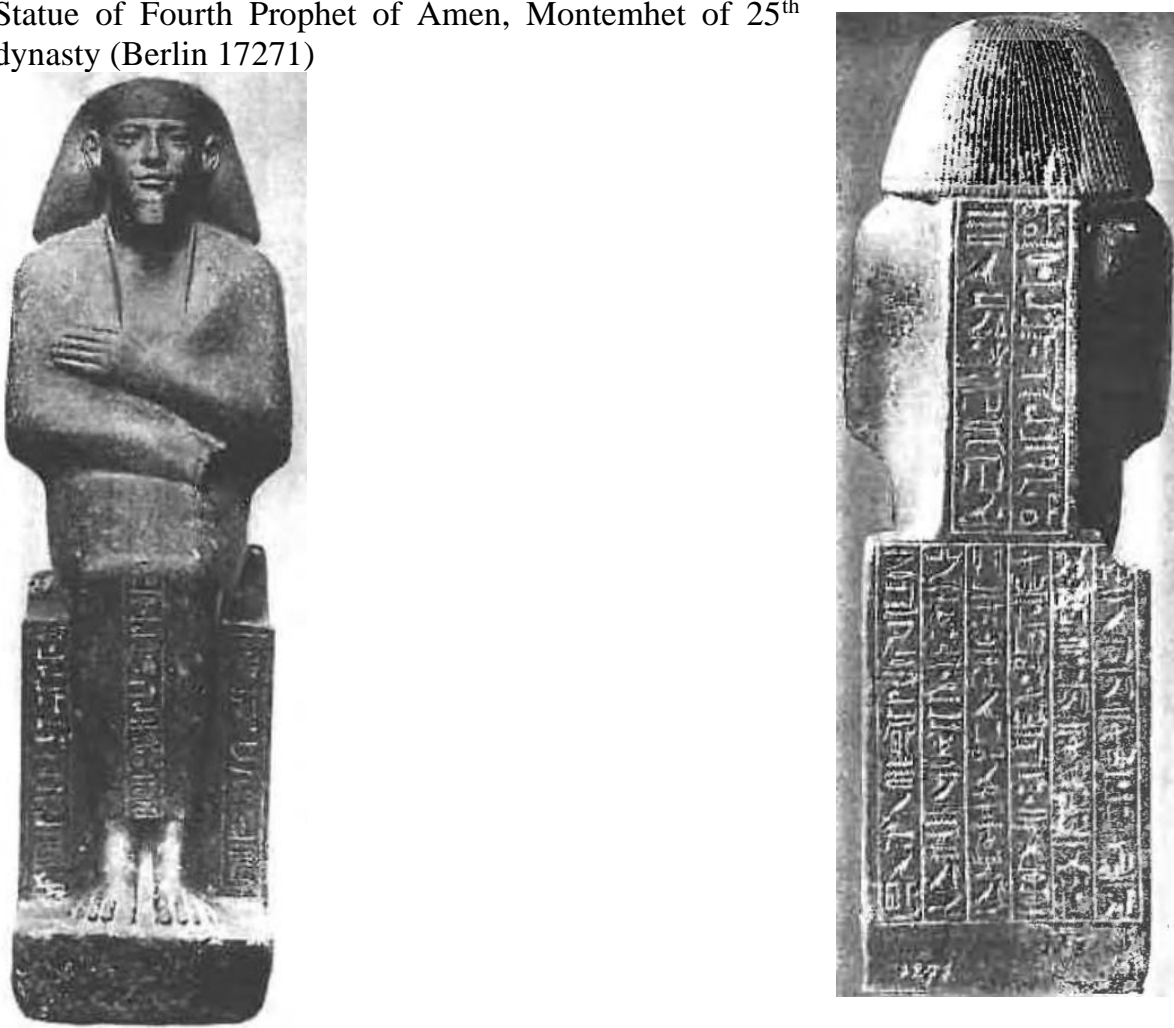

Leclant J. (1961). Montouemhat, quatrième prophète d'Amon. BDE 35, PL.xii, xv.

1 